\title{
Safety and efficacy of en bloc transurethral resection versus conventional transurethral resection for primary nonmuscle-invasive bladder cancer】a meta-analysis
}

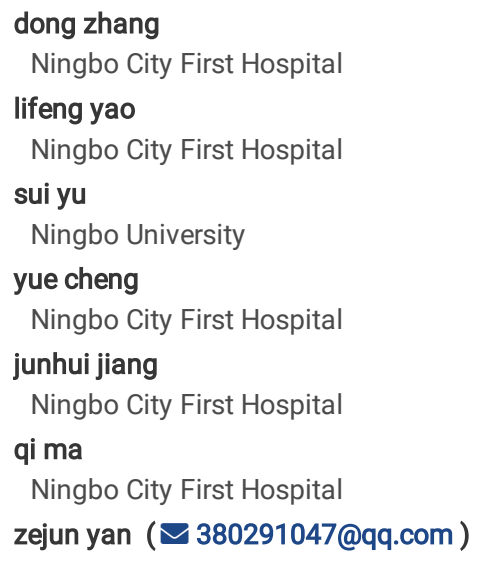




\section{Abstract}

Abstract Background: The purpose of this meta-analysis is to compare the safety and efficacy of en bloc transurethral resection of bladder tumorखEBRT $\square$ versus conventional transurethral resection of bladder tumor囚CTURBT囚. Methods: We performed a meta-analysis of relevant articles through January 2019 using PubMed, Embase and Cochrane Central Register to compare the safety and efficacy of EBRT versus CTURBT. The main endpoint included the operation

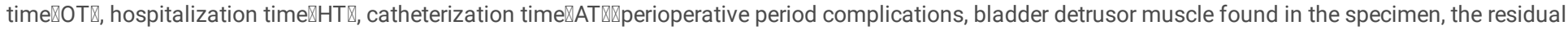
tumor on the base, the ratio of the same site recurrence and 12/24/36-month recurrence rate. Cochrane Collaboration's Revman software, version 5.3, was used for statistical analysis. Results: A total of 19 studies with 2651 patients were included 1369 underwent EBRT and 1282 underwent CTURBT. Patients treated with EBRT had a significantly lower AT, HT, obturator nerve reflex, bladder perforation, bladder irritation, postoperative complications and 24-month recurrence rate than those who underwent CTURBT. While no significant difference was found in terms of OT, the ratio of bladder detrusor muscle found in the specimen, the residual tumor on the base, 12-month recurrence rate, 36-month recurrence rate and the ratio of the same site recurrence. In mitomycin subgroup, EBRT was superior to CTURBT in terms of 12/24-month recurrence rate. Similarly, in the prospective subgroup and retrospective subgroup, EBRT had a lower 24-month recurrence rate than CTURBT. However, no significant difference was found in the low, intermediate and high-risk group in the light of 12-36 month recurrence rate. Conclusions: Based on the included 19 articles, EBRT had a significantly lower AT, HT, intraoperative and postoperative complications and 24-month recurrence rate than those treated with CTURBT. Well designed randomized controlled trials were needed to reevaluate these outcomes. Trial registration: This meta-analysis was reported in agreement with the PRISMA statement and was registered on PROSPERO 2019CRD42019121673. Keywords: bladder tumor; en bloc transurethral resection; conventional transurethral resection of bladder tumor; meta-analysis; complication

\section{Background}

Bladder cancer is one of the most common diseases in the genitourinary system. Approximately 549393 new bladder cancer patients have been diagnosed all over the world in 2018, with 199922 cases estimated cancer deaths[1]. For nonmuscle-invasive bladder cancer (NMIBC), CTURBT combined with intravesical chemotherapy or Bacille Calmette-Guerin囚BCG囚is the standard treatment[2]. However, complications such as obturator nerve reflex and bladder perforation may happen during the resection of lateral wall tumors, which is associated with urinary extravasation and neoplasm seeding[3]. Furthermore, the bladder tumor resected into fragments is contrary to the principle of tumor-free technique. Engilbertsson et al. had demonstrated that CTURBT induced the bladder tumor cell into the blood circulation[4]. However, it is now unknown whether CTURBT will increase the rate of metastatic disease. After the TURBT囚the probability of recurrence rate reaches $15-61 \%$ in 1 year, depending on the tumor characteristics and incomplete resection[2,5]. Thus, in order to achieve the complete resection, EBRT has been gradually applied in the treatment of bladder tumor during the past years[2]. It has the ability to resect neoplasm with a $1 \mathrm{~cm}$ margin from the tumor base and precisely separate detrusor muscle as well as connective tissue and comply with oncological principles. In addition, the capacity to remove the neoplasm may yield the merit of shorter intervention time, because it avoids piece-by-piece removal by CTURBT, additionally prolonged by necessity to perform repeated hemostasis so as to improve visibility[6,7].

HybridKnife, needle electrode and laser are the main methods for EBRT. A series of studies comparing EBRT and CTURBT have been reported[6-24]. Although the clinical recurrence rate between two approaches is controversial, less intraoperative and postoperative complications have been observed when undergoing EBRT. A meta-analysis published in 2016 revealed that EBRT had a lower 24-month recurrence rate than CTURBT[25]. However, recent 4 RCTs revealed that no significant difference was found in terms of 24-month, 18-month or 12-month recurrence rate[7,12-14]. Therefore an updated meta-analysis with robust evidence was needed. We aimed to synthesize the evidence-based data to assess the safety and efficacy of EBRT versus CTURBT for NMIBC.

\section{Methods}

\section{Inclusion and exclusion criteria}

The including criteria were as follows: retrospective/prospective/RCT trails; English language; full-text articles; and studies that compared EBRT with CTURBT in the treatment of primary NMIBC(Ta,T1,Tis). The diagnosis of NMIBC was demonstrated by cystoscopy or histological evaluation of tumor tissue. Casereports, reviews, abstracts, animal experiments and letters were excluded.

\section{Literature search and data sources}

We performed subject terms (MeSH) including "urinary bladder neoplasms" with their free words to search for relevant articles through January 2019 in PubMed, Embase and Cochrane Central Register. The complete search used for PubMed was (urinary bladder neoplasms [MeSH terms] OR urinary bladder neoplasms [Text word]) AND (en bloc resection OR laser OR needle electrode OR endoscopic submucosal dissection OR Hybrid knife) AND (conventional transurethral resection of bladder tumor OR TURBT). The reference lists of relevant studies were also checked to identify potential records. Literature search and screening articles were achieved by two authors independently. The consensus was reached by discussion if there was any disagreement.

\section{Data extraction}

One reviewer noted the study authors, date of publication, level of evidence, surgical method, tumor size, number of patients treated with EBRT or ETURBT, tumor grade, tumor T-stage, the method of intravesical instillation, OT, AT, HT, obturator nerve reflex, bladder perforation, bladder irritation, bladder detrusor 
muscle, postoperative complications, residual tumor on base, 12/24/36-month recurrence rate, same site recurrence rate. Dates were then verified by another reviewer.

\section{Quality assessment and statistical analysis}

The Evidence-Based Medicine in Oxford was used to assess the level of evidence of all included articles[26]. Cochrane risk of bias tool was used to assess the methodological quality of included RCTs[27]. Furthermore, according to the Newcastle-Ottawa scale (including patient selection, comparability of the study groups, and assessment of outcome)[28], we could assess the methodological quality of non-randomized controlled trials.

Dichotomous or continuous data on $\mathrm{OT}, \mathrm{AT}, \mathrm{HT}$, obturator nerve reflex, bladder perforation, bladder irritation, bladder detrusor muscle, postoperative complications, the residual tumor on base, 12/24/36-month recurrence rate and same site recurrence were analyzed through Review Manager software, version 5.3 (Cochrane Collaboration, Oxford, United Kingdom). Subgroup analyses were performed based on study type and different therapy of intravesical instillations. Mantel-Haenszel chi-square test and $\mathrm{I}^{2}$ statistic were performed to assess the impact of study heterogeneity on the result of the meta-analysis. If the P-value was $>0.1$ and $\mathrm{I}^{2}<50 \%$, the fixed-effect model was performed. Otherwise, the random effect model was applied for meta-analysis. We used the mean difference(MD) and odds ratio(OR) to compare continuous and dichotomous variables, respectively. Funnel plots were used to evaluate the publication bias. The confidence interval(Cl) was set at $95 \%$ and the $\mathrm{P}$-value $<0.05$ was identified as statistically significant.

\section{Results \\ Eligible Studies and Characteristics}

A total of 19 studies with 2651 patients were included in this meta-analysis $\$ 1369$ underwent EBRT and 1282 underwent CTURBT. The characteristics of the included articles were presented in Table 1. Of all articles, 4 were RCTs[7, 12-14], 3 were prospective studies[11, 15, 19] and 12 were retrospective studies[6, 810, 16-18, 20-24]. Laser, "button" shape electrode, loop electrode or HybridKnife were used in the EBRT group. Loop electrode was used in CTURBT group. Fig.1 summarized the inclusion process. We performed intravesical chemotherapy or Bacille Calmette-Guerin $\varangle \mathrm{BCG} \bigotimes$ for postoperative patients, mitomycin was used in 5 studies[8, 9,15-17], epirubicin was used in 7 studies[6,7,10,12,14,23,24], pirarubicin was used in 5 studies[13,18,20-22], BCG was used in 1 study[11] and BCG combined epirubicin[19] was used in 1 study.

\section{Quality Assessment of Included Studies}

We described the level of evidence of the 19 articles in Table 1 . According to the risk of bias graph, 4 RCTs were all considered high-quality studies, with $>3$ kinds of bias were at low risk (Fig 2). Furthermore, 11 non-randomised studies $[6,8,9,11,15-17,20-22,24]$ were considered of high quality due to the score $\geq 7$ stars (Table 1).

\section{Operative time, hospitalization time, catheterization time}

12 articles reported the $\mathrm{HT}, 15$ articles reported the AT, and 17 articles reported the OT. Based on 12 included articles[6-9,12,13,15,16,18,21,22,24], the patients treated with EBRT had significantly decreased HT compared with CTURBT( $<<0.00001)$. The MD was -1.30 , in favour of EBRT[(random effect) $95 \%$ confidence interval [Cl], -1.70 to -0.91; $p<0.00001$ ] (Table 2). Similarly, 15 articles[6-10,12,13,15,16,18,19,21-24] provided evidence that suggested that the difference in AT was significant between the two groups[MD, $-0.97 ; 95 \%$ [Cl], -1.30 to $-0.64 ; p<0.00001]$ (Table 2). Furthermore, no significantly difference was found in terms of OT[MD, $-0.56 ; 95 \%$ [Cl], -2.16 to $-1.04 ; p=0.49][6-10,12-16,18,21-23]$ (Table 2). While there was a high heterogeneity in all comparisons, which may come from the patient demographics, difference in types of surgery and tumor characteristics.

Table 2 The main result of this meta-analysis.

\section{Complications}

Where reported, the main intraoperative and postoperative side effects included: obturator nerve reflex[7-10,12,13,15,17-24], bladder perforation[6-10, $13,15,16,18,20-24]$, bladder irritation[6,7,9,16], urethral stricture, bleeding and fever[6,7,9,14-16,20,21,24]. According to the pooled articles, the patients treated with EBRT had significantly decreased the obturator nerve reflex[OR, 0.12;95\% [Cl], 0.07 to $0.19 ; \mathrm{p}<0.00001]$ (Table 2), bladder perforation[OR, $0.17 ; 95 \%$ [Cl], 0.09 to $0.35 ; p<0.00001$ ] (Table 2), bladder irritation[OR, $0.21 ; 95 \%$ [Cl], 0.14 to $0.32 ; p<0.00001$ ] (Table 2) and postoperative complications[OR, $0.40 ; 95 \%$ [Cl], 0.20 to $0.82 ; p=0.01$ ] (Table 2 ) when compared with ETURBT. There was no significant heterogeneity among the all comparisons.

\section{The residual tumor on the base}

The repeated biopsy in the base was performed by Zhang et al.[14, 18] after the tumor was resected. 2 pooled articles[14, 18] showed that CTURBT had similar residual tumor rate compared with EBRT[OR, 0.47;95\% [Cl], 0.07 to $3.27 ; \mathrm{p}=0.44]$ (Table 2). 


\section{Bladder detrusor muscle}

The bladder detrusor muscle in the specimen was showed in 4 articles[14,18,20,21]. Although there were $94 \%$ and $86.9 \%$ positive rate in EBRT and CTURBT group, respectively, no significant difference was found between two groups[OR, 3.59;95\% [Cl], 0.6 to 21.63; $p=0.16]$ (Table 2).

\section{2-month recurrence}

The 12-month recurrence rate between groups was compared in 8 studies $[6,7,10,14,16,18-20]$. The patients treated with EBRT had a lower 12 -recurrence rate. No significant difference was found between groups[OR, $0.77 ; 95 \%$ [Cl], 0.55 to $1.07 ; p=0.12]$.In subgroup analyses(Fig 3 ) according to the different therapy of intravesical instillations (Table 3), no difference was found between groups using epirubicin[OR, 0.92;95\% [Cl], 0.61 to $1.37 ; \mathrm{p}=0.68$ ] , pirarubicin[OR, 0.79;95\% [Cl], 0.29 to 2.18; $p=0.65$ ] or epirubicin combined with BCG[OR, 0.54;95\% [Cl], 0.19 to $1.58 ; p=0.26$ ] for NMIBC. However, based on 2 articles using mitomycin, the pooled $\mathrm{OR}$ is 0.31 [OR (fixed effect) $95 \% \mathrm{Cl}, 0.10$ to $0.93 ; \mathrm{p}=0.04$ ], which indicated EBRT had a lower 12-month recurrence rate than CTURBT. Subgroup was also performed based on the study type. Table 3 summarized the results.

Table 3 RCT, randomized controlled trail; BCG, Bacille Calmette-Guerin; NA, not applicable

\section{4-month recurrence}

A total of 1559 patients were included, 762 underwent EBRT and 797 underwent CTURBT. In meta-analysis, 12 pooled studies[6-11,13,15,16,22-24] showed that CTURBT had a apparently higher 24-month recurrence compared with EBRT[OR, $0.62 ; 95 \%$ [Cl], 0.48 to $0.80 ; p=0.0003$ ]. Subgroup analyses were conducted based on the different therapy of intravesical instillations. There were no significantly difference between two groups in the epirubicin subgroup[OR, $0.71 ; 95 \%$ [Cl], 0.45 to $1.10 ; p=0.13$ ] or pirarubicin subgroup[OR, $0.65 ; 95 \%$ [Cl], 0.36 to $1.16 ; p=0.14$ ]. However, in mitomycin[OR, $0.61 ; 95 \%$ [Cl], 0.41 to $0.90 ; p=0.01$ ] and BCG subgroups[OR, 0.24;95\% [Cl], 0.07 to $0.84 ;$ p=0.03] (Fig 4), the pooled results showed that patients treated with EBRT had a lower $24-\mathrm{month}$ recurrence. No significant heterogeneity was showed in all comparisons. Subgroup was also performed based on the study type. Table 3 summarized the results.

\section{6-month recurrence}

4 articles were analyzed for 36 -month recurrence as the outcome. 4 pooled studies[7, 14, 16, 20] including 203 patients showed that there were $29.6 \%$ and 32.4\% 36-month recurrence rate in EBRT and CTURBT group, respectively, but no significant difference was found between two groups[OR, $0.72 ; 95 \%$ [Cl], 0.37 to 1.39; $\mathrm{p}=0.32$ ] (Table 3). Our pooled estimate showed significant heterogeneity $\left(\mathrm{I}^{2}=58 \%\right)$, which may come from the Cheng's study. Because only HybridKnife was used for EBRT by Cheng, laser was used by the others.

\section{Same site recurrence}

5 included articles[11, 13, 18, 19, 23] evaluated the same site recurrence rate with the follow-up time between 12-38 months. Compared with the CTURBT, EBRT had a lower same site recurrence rate, while no significant difference was found between two groups[OR, $0.49 ; 95 \%$ [Cl], 0.21 to 1.14; $p=0.10]$ (Table 3).

\section{Low-risk, intermediate-risk, high-risk}

According to the postoperative pathologic examinations, patients were divided into the low-risk group $[6,9,13,14]$, intermediated-risk $[6,9,13,14]$ and high -risk group $[9,13,14]$. The main evidence for grouping was tumor size, tumor numbers, tumor category and tumor grade. No significant difference was found in terms of recurrence rate between $12-36$ months in the low-risk group[OR, 1.01;95\% [Cl], 0.63 to $1.63 ; \mathrm{p}=0.96$ ], intermediated-risk group[OR, 0.76;95\% [Cl], 0.47 to $1.23 ; p=0.26$ ] and high-risk group[OR, 0.82;95\% [Cl], 0.24 to $2.85 ; p=0.76]$ (Table 3$)$.

\section{Publication bias}

According to the funnel plots, although a publication bias exists in obturator nerve reflex. No significant publication bias was detected for our other results.

\section{Discussion}

This meta-analysis showed that compared with CTURBT, EBRT for NMIBC had a significantly lower AT, HT, obturator nerve reflex, bladder perforation, bladder irritation, postoperative complications and 24-month recurrence. While no significant difference was found in terms of OT, the ratio of bladder detrusor muscle found in the specimen, the residual tumor on the base, 12-month recurrence rate, 36-month recurrence rate and the ratio of the same site recurrence. In mitomycin subgroup, EBRT was superior to CTURBT in terms of 12/24-month recurrence rate significantly. Similarly, in the prospective subgroup and retrospective subgroup, EBRT had a lower 24-month recurrence rate than CTURBT. However, no significant difference was found in the low, intermediate and high-risk group in the light of 12-36 month recurrence rate. Therefore, the pooled data lead support to EBRT as a superior method for NMIBC. 
With the development of technology and equipment, CTURBT is widely used in the NMIBC. However, there are still some limitations needed to be solved. Firstly, a tumor with a diameter $>2 \mathrm{~cm}$ was inevitably resected piece-by-piece and then the fragments would be washed out through the cystoscope sheath naturally, which did not meet the tumor-free principle. Secondly, detrusor muscle is one of the yardsticks to assess the complete resection. The eschar in the specimen caused by electric coagulation would influence the accurate tumor infiltration depth, grading and staging. Third, complications such as obturator nerve reflex and bladder perforation may happen during the resection of lateral wall tumors[29]. To avoid the obturator nerve reflex, it is possible to make an incomplete resection potentially, which in turn, lead to increase the risk for early recurrence and tumor understaging[30]. EBRT is a modified method for NMIPC. EAU guidelines state that it has the ability to provide high -quality specimen including muscle layer in 96-100\% of cases[31-33]. Meanwhile, EBRT decreased the complications such as obturator nerve reflex, bladder perforation, bladder irritation and urethral stricture. Although in our meta-analysis, no significant difference was found in terms of bladder detrusor muscle found in the specimen, the residual tumor on the base and same site recurrence rate between groups, detrusor muscle positive rate in EBRT were superior to CTURBT group(94\% vs $86.9 \%)$. Similarly, EBRT showed a lower residual tumor on the base $(0.53 \%$ vs $1.55 \%)$ and same site recurrence rate( $3.74 \%$ vs $8.69 \%)$.

EBRT had a shorter HT, AT, fewer complications and lower 24-month recurrence rate than CTURBT in the treatment of NMIBC. This conclusion is similar to another meta-analysis published in 2016[25]. However, our meta-analysis also explored the differences between the two groups about the ratio of bladder detrusor muscle found in the specimen, the residual tumor on the base, 12-month recurrence rate, 36-month recurrence rate and the ratio of the same site recurrence. Furthermore, subgroups were performed based on the study types and tumor characteristics. Despite the fact that we expanded the sample size and increased the research area, 12 retrospective studies limited the validity of our results.

Intravesical chemotherapy or Bacille Calmette-Guerin囚BCG\for postoperative patients was applied. The duration and dosage of postoperative therapy were inconsistent. Therefore, we performed a subgroup analysis based on the different therapy of intravesical instillations to assess the 12/24-month recurrence rate. The pooled studies indicated that EBRT was superior to CTURBT significantly with regard to 12/24-month recurrence rate when patients received mitomycin. In other subgroups, EBRT had a lower recurrence rate, although no statistical significance. This result indicated that postoperative adjuvant therapy is an important factor which may influence the prognosis.

We performed a subgroup analysis to evaluate the 12/24-month recurrence rate based on the study type. No significant difference was found in terms of 12 month recurrence rate, but in the prospective subgroup $(\mathrm{P}=0.02)$ and retrospective subgroup $(\mathrm{P}=0.006)$, EBRT had a statistically significant lower 24 -month recurrence rate than CTURBT. Furthermore, in the RCTs subgroup, 2 pooled studies showed that $19 \%$ and $25 \% 24$-month recurrence rate were observed in EBRT and CTURBT group, embodying the advantages of EBRT.

We evaluated the heterogeneity of each study on the pooled results by excluding single study sequentially. The results showed that the heterogeneity remained at a high level in terms of OT, AT, HT and bladder detrusor muscle, which may arise from differences in tumor characteristics, demographics and surgical technology. However, in terms of 36-month recurrence, when excluded Cheng's study, the heterogeneity decreased from $58 \%$ to 0 , which indicated this study should be responsible for the heterogeneity of our included studies. Reading the articles, HybridKnife used by Cheng had a significantly lower 36 -recurrence rate that CTURBT $(\mathrm{P}=0.008)$, while other studies showed no difference was found when they used the laser. This might be the reason for this situation. Therefore, we excluded Cheng' research, the results of the sensitivity analysis showed that no significant difference was found as before[0R, $1.02 ; 95 \%$ [Cl], 0.70 to $1.49 ; p=0.91]$.

However, some limitations should be mentioned in this meta-analysis. First, tumor characteristics in our included articles are different. Some articles included Ta and T1, while other articles included Ta, T1 and Tis. Second, the mean follow-up time was only 12-36 months. The pooled studies showed EBRT had a lower 24-month recurrence rate than those treated with CTURBT. However, no significant difference was found in terms of 12 or $36-$ month recurrence rate. A long term follow-up time should be performed to compare the recurrence-free survival between groups. Third, we only included articles published in Embase, PubMed, and Cochrane Central Register, but case-reports, reviews, abstracts, animal experiments and letters were excluded, which may result in potential selection bias and language bias. Fourth, of all included 19 studies, 12 were retrospective studies, with a higher risk of bias. Fifth $\mathbb{m}$ more studies should compare the safety and efficacy of EBRT verse CTURBT based on the low-risk, intermediate-risk and high-risk. Finally, tumor recurrence rate may be influenced by other confounding factors such as age, diabetes mellitus, smoking and gene. All the limitations above attenuated the value of our meta-analysis.

\section{Conclusion}

Our pooled studies showed that EBRT had a significantly lower AT, HT, intraoperative and postoperative complications and 24-month recurrence rate than those treated with CTURBT. In addition, EBRT appeared to have a higher ratio of bladder detrusor muscle in the specimen, a lower ratio of residual tumor on the base and the same site recurrence, a lower ratio of 12-month and 36-month recurrence than CTURBT, while the difference was not statistically significant. Well designed randomized controlled trials were needed to reevaluate these outcomes.

\section{Abbreviations}

EBRT: en bloc transurethral resection of bladder tumor; CTURBT: conventional transurethral resection of bladder tumor; OT: operation time; HT: hospitalization time; AT: catheterization time; BCG: Bacille Calmette-Guerin; NMIBC: nonmuscle-invasive bladder cancer; RCT: randomized controlled trail; MD: mean difference; OR: odds ratio; $\mathrm{Cl}$ : confidence interval.

\section{Declarations}

\section{Acknowledgements}


Not applicable

Funding

This research is supported by Program from Medical and Health Science and Technology Project of Zhejiang Province(Grant No. 2019334160).

\section{Availability of data and materials}

Not applicable.

\section{Author contributions}

DZ, LFY, ZJY, QM: project designation; DZ, SY, LFY: literature search and screening; QM, JHJ: data extraction; DZ, ZJY, YC, JHJ: quality assessment and data analysis, manuscript writing and editing; All the authors read and approved the final version.

\section{Ethical approval and consent to participate}

Not applicable.

\section{Consent for publication}

Not applicable.

\section{Competing Interests}

The authors declare that they have no conflict of interest.

\section{References}

[1].Bray F, Ferlay J, Soerjomataram I, et al. Global cancer statistics 2018: GLOBOCAN estimates of incidence and mortality worldwide for 36 cancers in 185 countries. CA Cancer J Clin.2018,68: 394-424. https://doi.org/ 10.3322/caac.21492

[2].Babjuk M, Böhle A, Burger M, et al. EAU Guidelines on Non-Muscle-invasive Urothelial Carcinoma of the Bladder: Update 2016. Eur Urol.2017,71: 447-461. https://doi.org/10.1016/j.eururo.2016.05.041

[3]Nieder AM, Meinbach DS, Kim SS, et al. Transurethral bladder tumor resection: intraoperative and postoperative complications in a residency setting. J Urol.2005,174(6):2307-2309. https://doi.org/10.1097/01.ju.0000181797.19395.03

[4]Engilbertsson H, Aaltonen KE, Björnsson S, et al. Transurethral bladder tumor resection can cause seeding of cancer cells into the bloodstream. J Urol.2015,193(1):53-57. https://doi.org/10.1016/j.juro.2014.06.083

[5].Brausi M , Collette L , Kurth K, et al. Variability in the Recurrence Rate at First Follow-up Cystoscopy after TUR in Stage Ta T1 Transitional Cell Carcinoma of the Bladder: A Combined Analysis of Seven EORTC Studies. Eur Urol.2002,41(5):523-531. https://doi.org/10.1016/s0302-2838(02)00068-4

[6].Zhong C , Guo S , Tang Y , Xia S. Clinical observation on 2 micron laser for non-muscle-invasive bladder tumor treatment: single-center experience. World J Urol.2010,28(2):157-161. https://doi.org/10.1007/s00345-010-0532-8

[7].Liu H, Wu J, Xue S, et al. Comparison of the safety and efficacy of conventional monopolar and 2-micron laser transurethral resection in the management of multiple nonmuscle-invasive bladder cancer. J Int Med Res.2013,41(4):984-992. https://doi.org/10.1177/0300060513477001

[8].Zhu Y, Jiang X, Zhang J, Chen W, Shi B, Xu Z. Safety and Efficacy of Holmium Laser Resection for Primary Nonmuscle-Invasive Bladder Cancer Versus Transurethral Electroresection: Single-Center Experience. Urology.2008,72(3):608-612. https://doi.org/10.1016/j.urology.2008.05.028

[9].Song X, Yang D, Che X, et al. Comparing the Safety and Efficiency of Conventional Monopolar, Plasmakinetic, and Holmium Laser Transurethral Resection of Primary Non-muscle Invasive Bladder Cancer. J Endourol.2010, 24(1):69-73. https://doi.org/10.1089/end.2009.0171

[10].Tao W, Yang D, Shan Y, et al. Safety and efficacy of 120W high performance system greenlight laser vaporization for non-muscle-invasive bladder cancer. J Xray Sci Technol.2013,21(2):309-316. https://doi.org/10.1089/end.2009.0171

[11].Sureka SK, Agarwal V, Agnihotri S, Kapoor R, Srivastava A, Mandhani A . Is en-bloc transurethral resection of bladder tumor for non-muscle invasive bladder carcinoma better than conventional technique in terms of recurrence and progression?: A prospective study. Indian J Urol.2014,30(2):144-149.

https://doi.org/10.4103/0970-1591.126887 
[12].Chen X, Liao J, Chen L, et al. En bloc transurethral resection with 2-micron continuous-wave laser for primary non-muscle-invasive bladder cancer: a randomized controlled trial. World J Urol.2015,33(7):989-995. https://doi.org/10.1007/s00345-014-1342-1

[13].Xu Y, Guan W, Chen W, et al.Comparing the treatment outcomes of potassium-titanyl-phosphate laser vaporization and transurethral electroresection for primary nonmuscle-invasive bladder cancer: A prospective, randomized study. Lasers Surg Med.2015,47(4):306-311. https://doi.org/10.1002/lsm.22342

[14].Zhang X, Feng C, Zhu W, et al. Two Micrometer Continuous-Wave Thulium Laser Treating Primary Non-Muscle-Invasive Bladder Cancer: Is It Feasible? A Randomized Prospective Study. Photomed Laser Surg.2015,33(10):517-523. https://doi.org/10.1089/pho.2015.3913

[15].Chen J, Zhao Y, Wang S, et al. Green-light laser en bloc resection for primary non-muscle-invasive bladder tumor versus transurethral electroresection: A prospective, nonrandomized two-center trial with 36-month follow-up. Lasers Surg Med.2016,48(9):859-865. https://doi.org/10.1002/lsm.22565

[16].D'Souza N, Verma A. Holmium laser transurethral resection of bladder tumor: Our experience. Uro Ann.2016,8(4):439-443. https://doi.org/ 10.4103/09747796.190815

[17].Cheng B, Qiu X, Li H, Yang G. The safety and efficacy of front-firing green-light laser endoscopic en bloc photoselective vapo-enucleation of non-muscleinvasive bladder cancer. Ther Clin Risk Manag Volume.2017, 13:983-988. https://doi.org/10.2147/TCRM.S141900

[18].Zhang K, Xing J, Li W, Wu Z, Chen B, Bai D. A novel transurethral resection technique for superficial bladder tumor: retrograde en bloc resection. World J Surg Oncol.2017,15(1):125. https://doi.org/10.1186/s12957-017-1192-6

[19].Bălan GX, Geavlete PA, Georgescu DA, et al. Bipolar en bloc tumor resection versus standard monopolar TURBT - which is the best way to go in noninvasive bladder cancer?. Rom J Morphol Embryol.2018,59: 773-780.

[20].Cheng Y, Sun Y, Li J et al. Transurethral endoscopic submucosal en bloc dissection for nonmuscle invasive bladder cancer: A comparison study of HybridKnife-assisted versus conventional dissection technique. J Cancer Res Ther.2018,14: 1606-1612. https://doi.org/10.4103/jcrt.JCRT_786_17

[21].Li K, Xu Y, Tan M, Xia S, Xu Z, Xu D. A retrospective comparison of thulium laser en bloc resection of bladder tumor and plasmakinetic transurethral resection of bladder tumor in primary non-muscle invasive bladder cancer. Lasers Med Sci.2019,34(1):85-89. https://doi.org/ 10.1007/s10103-018-2604-8

[22].Xu H , Ma J , Chen Z , et al. Safety and Efficacy of en Bloc Transurethral Resection with 1.9Mm Vela Laser for Treatment of Non-Muscle-Invasive Bladder Cancer. Urology.2018,113:246-250. https://doi.org/ 10.1016/j.urology.2017.11.030

[23].Yang D, Xue B, Zang Y, et al. Efficacy and Safety of Potassium-Titanyl-Phosphate Laser Vaporization for Clinically Non-Muscle Invasive Bladder Cancer. Urol J.2014,11(1):1258-1263. https://doi.org/ 10.1159/000357641

[24].Huang J, Hu Y, Liu M, Wang G, Peng B, Yao X. Comparative study of 2 um laser versus Holmium laser for the resection of non-muscle invasive bladder cancer. Int J Clin Exp Med.2016,9(12):23618-23623. https://doi.org/10.4172/2161-1076.1000246

[25].Wu Y, Lin T, Chen S, et al. Comparison of the efficacy and feasibility of en bloc transurethral resection of bladder tumor versus conventional transurethral resection of bladder tumor. Medicine.2016,95(45):e5372. https://doi.org/10.1097/MD.0000000000005372

[26].Wallace D K.Evidence-based medicine and levels of evidence. Am Orthopt J.2010, 60(1):2. https://doi.org/10.3368/aoj.60.1.2

[27].Higgins J P, Altman DG,Gøtzsche PC et al. The Cochrane Collaboration's tool for assessing risk of bias in randomised trials. BMJ.2011,343: d5928. https://doi.org/10.1136/bmj.d5928

[28].Stang A. Critical evaluation of the Newcastle-Ottawa scale for the assessment of the quality of nonrandomized studies in meta-analyses. Eur $\mathrm{J}$ Epidemiol.2010,25(9):603-605. https://doi.org/10.1007/s10654-010-9491-z

[29]Golan S, Baniel J, Lask D, Livne PM, Yossepowitch O. Transurethral resection of bladder tumour complicated by perforation requiring open surgical repair clinical characteristics and oncological outcomes. BJU Int.2011,107(7):1065-1068. https://doi.org/10.1111/j.1464-410X.2010.09696.x

[30]Mariappan P, Zachou A, Grigor KM. Detrusor muscle in the first, apparently complete transurethral resection of bladder tumour specimen is a surrogate marker of resection quality, predicts risk of early recurrence, and is dependent on operator experience. Eur Urol.2010,57(5):843-849.

https://doi.org/10.1016/j.eururo.2009.05.047

[31] Kramer MW, Altieri V, Hurle R, et al. Current Evidence of Transurethral En-bloc Resection of Nonmuscle Invasive Bladder Cancer. Eur Urol Focus.2017, 3(6):567-576. https://doi.org/10.3109/13645706.2014.880065

[32]Kramer MW, Rassweiler JJ, Klein J, et al. En bloc resection of urothelium carcinoma of the bladder (EBRUC): a European multicenter study to compare safety, efficacy, and outcome of laser and electrical en bloc transurethral resection of bladder tumor. World J Urol.2015,33(12):1937-1943.

https://doi.org/10.1007/s00345-015-1568-6

[33]Migliari R, Buffardi A, Ghabin H. Thulium Laser Endoscopic En Bloc Enucleation of Nonmuscle-Invasive Bladder Cancer. J Endourol.2015, 29(11):12581262. https://doi.org/10.1089/end.2015.0336

Page $7 / 14$ 
Table 1 Characteristics of included studies

\begin{tabular}{|c|c|c|c|c|c|c|c|c|c|c|c|c|c|}
\hline \multirow[t]{2}{*}{ Study } & \multirow[t]{2}{*}{ Study design } & \multirow[t]{2}{*}{ LOE } & \multirow[t]{2}{*}{ Surgical method } & \multicolumn{2}{|c|}{ Tumor size } & \multirow{2}{*}{$\begin{array}{c}\begin{array}{c}\text { No. of } \\
\text { patients }\end{array} \\
\begin{array}{l}\text { EBRT } \\
\text { CTURBT }\end{array}\end{array}$} & \multicolumn{3}{|c|}{ Grade } & \multicolumn{3}{|c|}{ T-stage } & \multirow[t]{2}{*}{$\mathrm{P} / \mathrm{N}$} \\
\hline & & & & EBRT & CTURBT & & & EBRT & CTURBT & & EBRT & CTURBT & \\
\hline $\begin{array}{l}\text { Zhu et } \\
\text { al.2008 }\end{array}$ & Retrospective & $3 \mathrm{~b}$ & $\begin{array}{c}\text { Holmium } \\
\text { laser/CTURBT }\end{array}$ & $\begin{array}{r}\leq 3 \mathrm{~cm} 95 \\
\square 3 \mathrm{~cm} 6\end{array}$ & $\begin{array}{ll}104 & 7\end{array}$ & $101 / 111$ & $\begin{array}{ll}1 & \\
2 & 3\end{array}$ & $\begin{array}{l}36 \\
54 \\
9\end{array}$ & $\begin{array}{c}38 \\
63 \\
10\end{array}$ & $\begin{array}{l}\mathrm{Ta} \\
\mathrm{T} 1\end{array}$ & 6734 & $70 \quad 41$ & \\
\hline $\begin{array}{l}\text { Zhong1 } \\
\text { et } \\
\text { al.2010 }\end{array}$ & Retrospective & $3 \mathrm{~b}$ & $\begin{array}{c}\text { 2-micron } \\
\text { laser/CTURBT }\end{array}$ & 2.23 & 1.54 & $30 / 42$ & $\begin{array}{c}\text { LMP } \\
\text { LG } \\
\text { HG }\end{array}$ & $\begin{array}{l}421 \\
5\end{array}$ & $\begin{array}{ll}7 & 26 \\
& 9\end{array}$ & $\begin{array}{l}\text { Ta } \\
\text { T1 } \\
\text { Cis }\end{array}$ & $5^{23} 2$ & $\begin{array}{ll}30 & \\
8 & 4\end{array}$ & \\
\hline $\begin{array}{l}\text { Zhong2 } \\
\text { et } \\
\text { al.2010 }\end{array}$ & Retrospective & $3 \mathrm{~b}$ & $\begin{array}{c}\text { Holmium } \\
\text { laser/CTURBT }\end{array}$ & 1.38 & 1.54 & $25 / 42$ & $\begin{array}{l}\text { LMP } \\
\text { LG } \\
\text { HG }\end{array}$ & $\begin{array}{c}318 \\
4\end{array}$ & $\begin{array}{ll}7 & 26 \\
& 9\end{array}$ & $\begin{array}{l}\text { Ta } \\
\text { T1 } \\
\text { Cis }\end{array}$ & $5^{19} 1$ & $\begin{array}{r}30 \\
8 \\
4\end{array}$ & \\
\hline $\begin{array}{l}\text { Liu et } \\
\text { al.2013 }\end{array}$ & RCT & $2 \mathrm{~b}$ & $\begin{array}{c}\text { 2-micron } \\
\text { laser/CTURBT }\end{array}$ & 1.31 & 1.28 & $64 / 56$ & $\begin{array}{c}\text { LMP } \\
\text { LG } \\
\text { HG }\end{array}$ & $\begin{array}{l}11 \\
46 \\
7\end{array}$ & $\begin{array}{ll}10 & \\
41 & 5\end{array}$ & $\begin{array}{l}\mathrm{Ta} \\
\mathrm{T} 1\end{array}$ & $\begin{array}{ll}37 & 27\end{array}$ & $34 \quad 22$ & \\
\hline $\begin{array}{c}\text { Sureka } \\
\text { et } \\
\text { al.2015 }\end{array}$ & Prospective & $2 \mathrm{~b}$ & EBRT/CTURBT & 2.8 & 3.3 & $21 / 24$ & NM & NM & NM & $\begin{array}{l}\mathrm{Ta} \\
\mathrm{T} 1\end{array}$ & 129 & $13 \quad 11$ & \\
\hline $\begin{array}{l}\text { Chen et } \\
\text { al.2015 }\end{array}$ & RCT & $2 \mathrm{~b}$ & $\begin{array}{c}\text { 2-micron } \\
\text { laser/CTURBT }\end{array}$ & 2.6 & 2.3 & $71 / 71$ & $\begin{array}{c}\text { LMP } \\
\text { LG } \\
\text { HG }\end{array}$ & $\begin{array}{c}543 \\
23\end{array}$ & $\begin{array}{cc}9 & 45 \\
& 17\end{array}$ & $\begin{array}{l}\text { Ta } \\
\text { T1 } \\
\text { Cis }\end{array}$ & $\begin{array}{cc}43 \\
25 & 3\end{array}$ & $\begin{array}{cc}55 & 15 \\
1\end{array}$ & \\
\hline $\begin{array}{c}\text { Xu et } \\
\text { al.2015 }\end{array}$ & $\mathrm{RCT}$ & $2 b$ & $\begin{array}{c}\text { 2-micron } \\
\text { laser/CTURBT }\end{array}$ & $\begin{array}{l}\leq 3 \mathrm{~cm} 81 \\
\quad \square 3 \mathrm{~cm} 18\end{array}$ & $\begin{array}{l}\leq 3 \mathrm{~cm} 79 \\
\square 3 \mathrm{~cm} 15\end{array}$ & $116 / 113$ & $\begin{array}{ll}1 & \\
2 & \\
& 3\end{array}$ & $\begin{array}{c}50 \\
39 \\
10\end{array}$ & $\begin{array}{ll}48 & \\
41 & 5\end{array}$ & $\begin{array}{l}\mathrm{Ta} \\
\mathrm{T} 1\end{array}$ & 918 & $82 \quad 12$ & \\
\hline $\begin{array}{c}\text { Zhang } \\
\text { et } \\
\text { al.2015 }\end{array}$ & RCT & $2 \mathrm{~b}$ & $\begin{array}{c}\text { 2-micron } \\
\text { laser/CTURBT }\end{array}$ & $\begin{array}{l}\leq 3 \mathrm{~cm} 98 \\
\quad \square 5 \mathrm{~cm} 51\end{array}$ & $\begin{array}{l}\leq 3 \mathrm{~cm} 95 \\
\square 5 \mathrm{~cm} 48\end{array}$ & $149 / 143$ & $\begin{array}{c}\text { G0 } \\
\text { G1 } \\
\text { G2 }\end{array}$ & $\begin{array}{c}87 \\
548\end{array}$ & $\begin{array}{ll}75 & \\
60 & 8\end{array}$ & $\begin{array}{l}\mathrm{Ta} \\
\mathrm{T} 1\end{array}$ & $\begin{array}{r}106 \\
43\end{array}$ & 10736 & \\
\hline $\begin{array}{l}\text { Cheng } \\
\text { et } \\
\text { al.2017 }\end{array}$ & Retrospective & $3 \mathrm{~b}$ & $\begin{array}{c}\text { KTP } \\
\text { laser/CTURBT }\end{array}$ & 1.65 & 1.5 & $34 / 30$ & $\begin{array}{l}\text { Low } \\
\text { High }\end{array}$ & 192 & $20 \quad 0$ & $\begin{array}{l}\mathrm{Ta} \\
\mathrm{T} 1\end{array}$ & 1416 & 1315 & \\
\hline $\begin{array}{c}\text { Zhang } \\
\text { et } \\
\text { al.2017 }\end{array}$ & Retrospective & $3 \mathrm{~b}$ & EBRT/CTURBT & $\begin{array}{l}\leq 3 \mathrm{~cm} 32 \\
\square 3 \mathrm{~cm} 8\end{array}$ & $\begin{array}{l}\leq 3 \mathrm{~cm} 38 \\
\square 3 \mathrm{~cm} 12\end{array}$ & $40 / 50$ & $\begin{array}{l}\text { LMP } \\
\text { LG } \\
\text { HG }\end{array}$ & $\begin{array}{c}922 \\
9\end{array}$ & $\begin{array}{ll}12 & 23 \\
15\end{array}$ & $\begin{array}{l}\mathrm{Ta} \\
\mathrm{T} 1\end{array}$ & $15 \quad 25$ & $27 \quad 23$ & \\
\hline $\begin{array}{c}\text { Balan } \\
\text { et } \\
\text { al.2018 }\end{array}$ & Prospective & $2 \mathrm{~b}$ & EBRT/CTURBT & 1.82 & 1.69 & $45 / 45$ & NM & NM & NM & $\begin{array}{l}\mathrm{Ta} \\
\mathrm{T} 1\end{array}$ & 2421 & $23 \quad 22$ & $\mathrm{E} \mathrm{a}$ \\
\hline $\begin{array}{l}\text { Yang et } \\
\text { al.2013 }\end{array}$ & Retrospective & $3 b$ & $\begin{array}{c}\text { KTP } \\
\text { laser/CTURBT }\end{array}$ & $\begin{aligned} & \leq 3 \mathrm{~cm} 24 \\
& \square 3 \mathrm{~cm} 4\end{aligned}$ & $\begin{array}{l}\leq 3 \mathrm{~cm} 26 \\
\square 3 \mathrm{~cm} 6\end{array}$ & $28 / 32$ & $\begin{array}{ll}1 & \\
2 & 3\end{array}$ & $\begin{array}{c}15 \\
103\end{array}$ & $\begin{array}{c}16 \\
10\end{array}$ & $\begin{array}{l}\mathrm{Ta} \\
\mathrm{T} 1\end{array}$ & $8 \quad 20$ & $7 \quad 25$ & \\
\hline $\begin{array}{c}\text { Tao et } \\
\text { al.2013 }\end{array}$ & Retrospective & $3 b$ & $\begin{array}{c}\text { KTP } \\
\text { laser/CTURBT }\end{array}$ & 2.1 & 1.9 & $74 / 84$ & $\begin{array}{c}\text { LMP } \\
\text { LG } \\
\text { HG }\end{array}$ & $\begin{array}{c}960 \\
5\end{array}$ & $\begin{array}{ll}10 & \\
68 & 6\end{array}$ & $\begin{array}{l}\text { Ta } \\
\mathrm{T} 1 \\
\text { Cis }\end{array}$ & $\begin{array}{cc}50 & \\
23 & 1\end{array}$ & $\begin{array}{cc}61 & \\
21 & 2\end{array}$ & \\
\hline $\begin{array}{l}\text { Cheng } \\
\text { et } \\
\text { al.2018 }\end{array}$ & Retrospective & $3 \mathrm{~b}$ & $\begin{array}{l}\text { HybridKnife/ } \\
\text { CTURBT }\end{array}$ & 2.5 & 2.8 & $95 / 98$ & $\begin{array}{l}\text { LMP } \\
\text { LG } \\
\text { HG }\end{array}$ & $\begin{array}{c}548 \\
40\end{array}$ & $\begin{array}{ll}8 & 37 \\
& 48\end{array}$ & $\begin{array}{l}\mathrm{Ta} \\
\mathrm{T} 1\end{array}$ & $52 \quad 43$ & $54 \quad 44$ & \\
\hline $\begin{array}{l}\text { D'souza } \\
\text { et } \\
\text { al.2016 }\end{array}$ & Retrospective & $3 \mathrm{~b}$ & $\begin{array}{c}\text { Holmium } \\
\text { laser/CTURBT }\end{array}$ & 1.41 & 1.58 & $27 / 23$ & $\begin{array}{l}\text { LMP } \\
\text { LG } \\
\text { HG }\end{array}$ & $\begin{array}{c}520 \\
2\end{array}$ & $\begin{array}{ll}4 & 16 \\
& 3\end{array}$ & $\begin{array}{l}\mathrm{Ta} \\
\mathrm{T} 1\end{array}$ & $16 \quad 11$ & 15 & \\
\hline $\begin{array}{l}\text { Song et } \\
\text { al.2010 }\end{array}$ & Retrospective & $3 b$ & $\begin{array}{c}\text { Holmium } \\
\text { laser/CTURBT }\end{array}$ & 1.85 & 1.74 & $64 / 51$ & $\begin{array}{c}\text { LMP } \\
\text { LG } \\
\text { HG }\end{array}$ & $\begin{array}{c}539 \\
20\end{array}$ & $\begin{array}{ll}4 & 33 \\
14\end{array}$ & $\begin{array}{l}\text { Ta } \\
\text { T1 } \\
\text { Cis }\end{array}$ & $\begin{array}{c}36 \\
23 \quad 5\end{array}$ & $\begin{array}{ll}30 & \\
17 & 4\end{array}$ & \\
\hline $\begin{array}{l}\text { Huang1 } \\
\text { et } \\
\text { al.2016 }\end{array}$ & Retrospective & $3 b$ & $\begin{array}{c}\text { 2-micron } \\
\text { laser/CTURBT }\end{array}$ & 1.63 & 1.53 & $70 / 70$ & $\begin{array}{l}\text { LMP } \\
\text { LG } \\
\text { HG }\end{array}$ & $\begin{array}{l}20 \\
40 \\
10\end{array}$ & ${ }^{18} 6^{18} 6$ & $\begin{array}{l}\text { Ta } \\
\text { T1 } \\
\text { Cis }\end{array}$ & $\begin{array}{cc}40 & \\
23 & 7\end{array}$ & $\begin{array}{cc}35 & \\
27 & 8\end{array}$ & \\
\hline $\begin{array}{l}\text { Huang2 } \\
\text { et } \\
\text { al.2016 }\end{array}$ & Retrospective & $3 b$ & $\begin{array}{c}\text { Holmium } \\
\text { laser/CTURBT }\end{array}$ & 1.58 & 1.53 & $70 / 70$ & $\begin{array}{c}\text { LMP } \\
\text { LG } \\
\text { HG }\end{array}$ & $\begin{array}{c}15 \\
487\end{array}$ & $\begin{array}{ll}18 & \\
46 & 6\end{array}$ & $\begin{array}{l}\text { Ta } \\
\text { T1 } \\
\text { Cis }\end{array}$ & $\begin{array}{c}37 \\
285\end{array}$ & $\begin{array}{ll} & 35 \\
27 & 8\end{array}$ & \\
\hline $\begin{array}{c}\text { Xu et } \\
\text { al.2017 }\end{array}$ & Retrospective & $3 b$ & $\begin{array}{c}\text { Holmium } \\
\text { laser/CTURBT }\end{array}$ & 2.3 & 2.2 & $26 / 44$ & $\begin{array}{l}\text { LMP } \\
\text { LG } \\
\text { HG }\end{array}$ & $\begin{array}{c}414 \\
8\end{array}$ & $\begin{array}{cc}3 & 28 \\
& 13\end{array}$ & $\begin{array}{l}\text { Ta } \\
\text { T1 }\end{array}$ & $10 \quad 12$ & 25 & \\
\hline $\begin{array}{l}\text { Chen et } \\
\text { al.2016 }\end{array}$ & Prospective & $2 \mathrm{~b}$ & $\begin{array}{c}\text { Green } \\
\text { laser/CTURBT }\end{array}$ & 1.85 & 1.71 & $83 / 75$ & $\begin{array}{c}\text { LMP } \\
\text { LG } \\
\text { HG }\end{array}$ & $\begin{array}{l}12 \\
61 \\
10\end{array}$ & $\begin{array}{rr}8 & \\
55 & 12\end{array}$ & $\begin{array}{l}\mathrm{Ta} \\
\mathrm{T} 1\end{array}$ & $\begin{array}{c}70 \\
13\end{array}$ & $64 \quad 11$ & \\
\hline
\end{tabular}

RCT, randomized control trial; NM, not mention; CTURBT, conventional transurethral resection of bladder tumor; EBRT, en bloc resection of bladder tumor; LMP, low malignant potential; LG, low grade; HG, high grade; P, pirarubicin; M, mitomycin; E, epirubicin; BCG, Bacille Calmette-Guerin. 
Table 2 The main result of this meta-analysis

\begin{tabular}{cccccc}
\hline Endpoint & No.of studies & Heterogeneity & \multirow{2}{*}{ OR/MD[95\%CI] } \\
\cline { 3 - 4 } & & \multicolumn{2}{c}{$\mathrm{I}^{2} \%$} & $\mathrm{p}$ & \\
\hline Operation time & 17 & 72 & 0.49 & $-0.56[-2.16,1.04]$ \\
\hline Catheterization time & 17 & 95 & $<0.00001$ & $-0.97[-1.30,-0.64]$ \\
\hline Hospitalization time & 14 & 95 & $<0.00001$ & $-1.30[-1.70,-0.91]$ \\
\hline Obturator nerve reflex & 16 & 43 & $<0.00001$ & $0.12[0.07,0.19]$ \\
\hline Bladder perforation & 16 & 0 & $<0.00001$ & $0.17[0.09,0.35]$ \\
\hline Bladder irritation & 5 & 41 & $<0.00001$ & $0.21[0.14,0.32]$ \\
\hline Postoperative complications & 11 & 0 & 0.01 & $0.40[0.20,0.82]$ \\
\hline Residual tumor on the base & 2 & 0 & 0.44 & $0.47[0.07,3.27]$ \\
\hline Bladder detrusor tumor & 4 & 85 & 0.16 & $3.59[0.60,21.63]$ \\
\hline
\end{tabular}

Table 3 RCT, randomized controlled trail; BCG, Bacille Calmette-Guerin; NA, not applicable

\begin{tabular}{|c|c|c|c|c|c|}
\hline & \multirow[t]{2}{*}{ Subgroup } & \multirow[t]{2}{*}{ No.of studies } & \multicolumn{2}{|c|}{ Heterogeneity } & \multirow[t]{2}{*}{$\mathrm{OR} / \mathrm{MD}[95 \% \mathrm{CI}]$} \\
\hline & & & $I^{2} \%$ & $\mathrm{p}$ & \\
\hline \multirow[t]{7}{*}{ 12-month recurrence } & RCT & 2 & 0 & 0.93 & $0.98[0.62,1.55]$ \\
\hline & Prospective & 1 & NA & 0.26 & $0.54[0.19,1.58]$ \\
\hline & Retrospective & 6 & 0 & 0.06 & $0.59[0.33,1.03]$ \\
\hline & Epirubicin & 5 & 0 & 0.68 & $0.92[0.61,1.37]$ \\
\hline & Mitomycin & 2 & 23 & 0.04 & $0.31[0.10,0.93]$ \\
\hline & Pirarucin & 1 & NA & 0.65 & $0.79[0.29,2.18]$ \\
\hline & Epirubicin+BCG & 1 & NA & 0.26 & $0.77[0.55,1.07]$ \\
\hline \multirow[t]{7}{*}{ 24-month recurrence } & RCT & 2 & 0 & 0.19 & $0.70[0.41,1.19]$ \\
\hline & Prospective & 2 & 19 & 0.02 & $0.43[0.21,0.89]$ \\
\hline & Retrospective & 10 & 0 & 0.006 & $0.64[0.47,0.88]$ \\
\hline & Epirubicin & 7 & 0 & 0.13 & $0.71[0.45,1.10]$ \\
\hline & Mitomycin & 4 & 0 & 0.01 & $0.61[0.41,0.90]$ \\
\hline & Pirarucin & 2 & 0 & 0.14 & $0.65[0.36,1.16]$ \\
\hline & BCG & 1 & NA & 0.03 & $0.24[0.07,0.84]$ \\
\hline 36-month recurrence & & 4 & 58 & 0.32 & $0.72[0.37,1.39]$ \\
\hline Same site recurrence & & 5 & 0 & 0.10 & $0.49[0.21,1.14]$ \\
\hline \multirow[t]{3}{*}{ Recurrence } & Low-risk & 5 & 0 & 0.96 & $1.01[0.63,1.63]$ \\
\hline & Intermediate-risk & 4 & 0 & 0.26 & $0.76[0.47,1.23]$ \\
\hline & High-risk & 3 & 0 & 0.76 & $0.82[0.24,2.85]$ \\
\hline
\end{tabular}

\section{Figures}




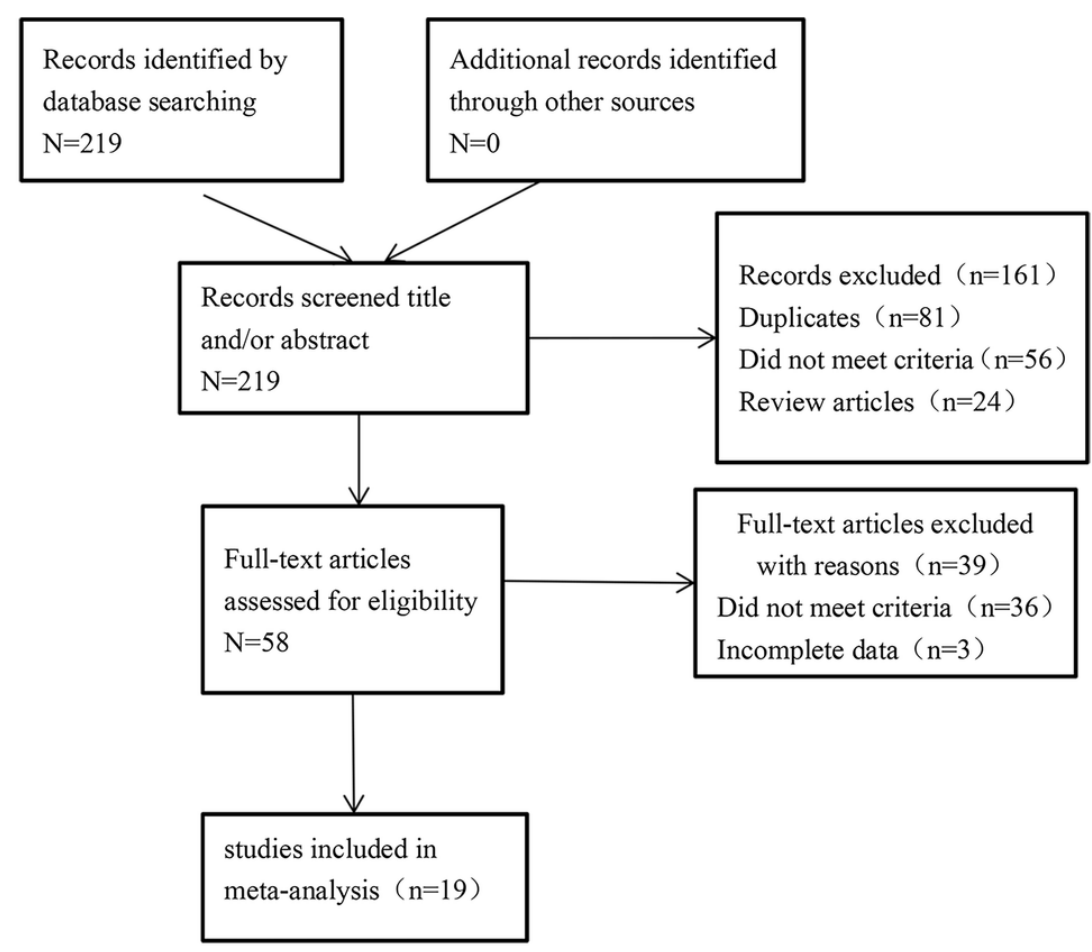

Figure 1

Flow diagram of the study selection process. 


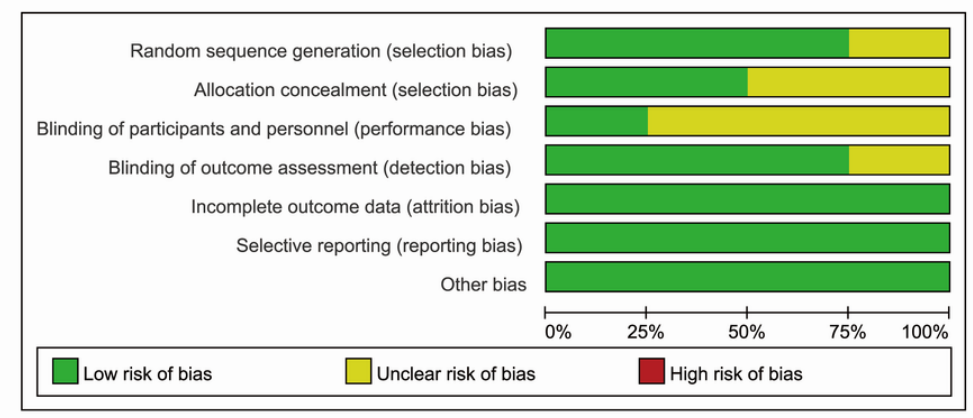

\section{Figure 2}

Overall quality assessment for included randomized controlled trials. 


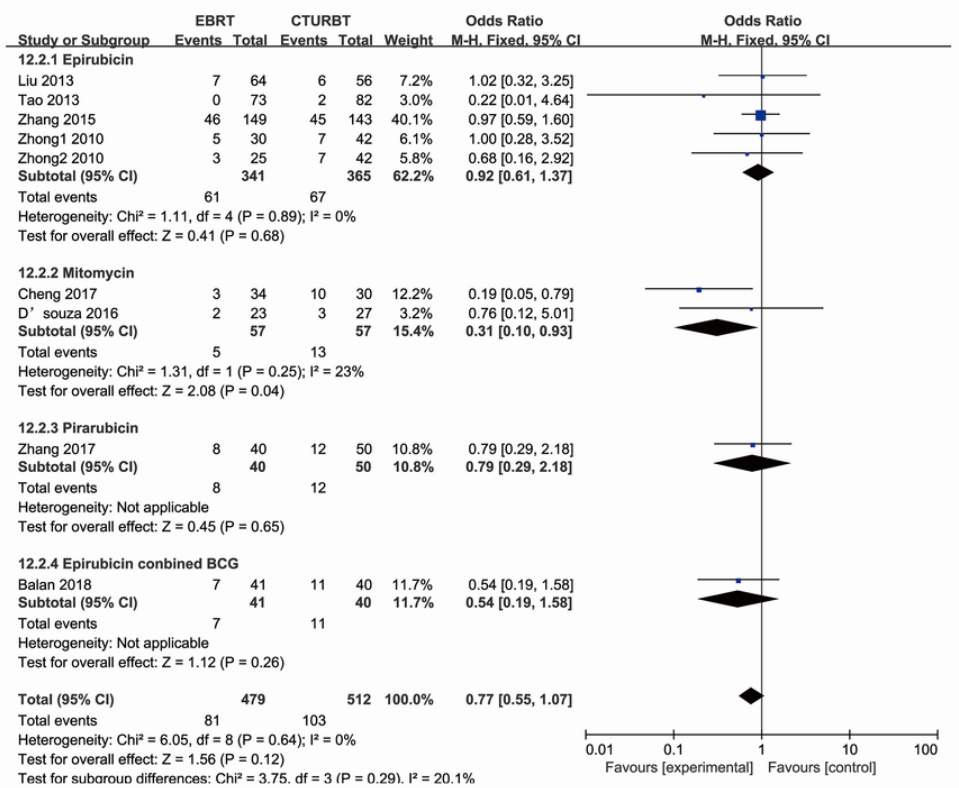

Test for subaroun differences: $\mathrm{Ch}^{2}=3.75$. df $=3(P=0.29) .1^{2}=20.1 \%$

\section{Figure 3}

12-month recurrence based on the different therapy of intravesical instillations 


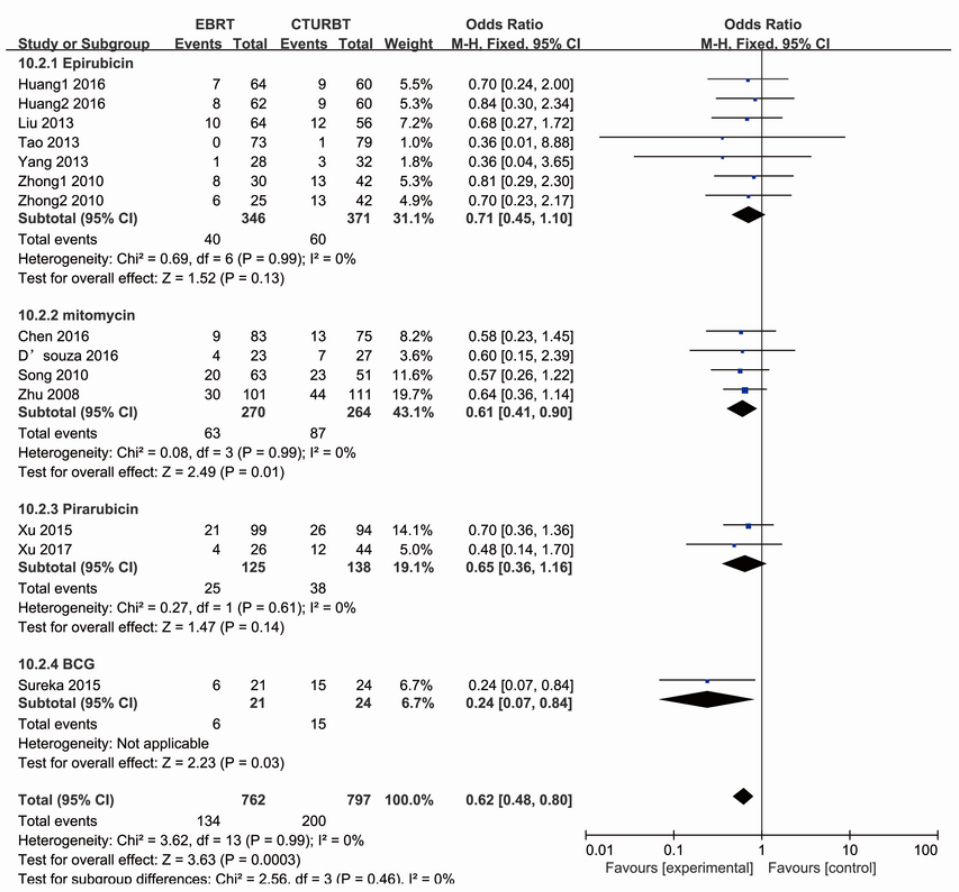

\section{Figure 4}

24-month recurrence rate based on the different therapy of intravesical instillations
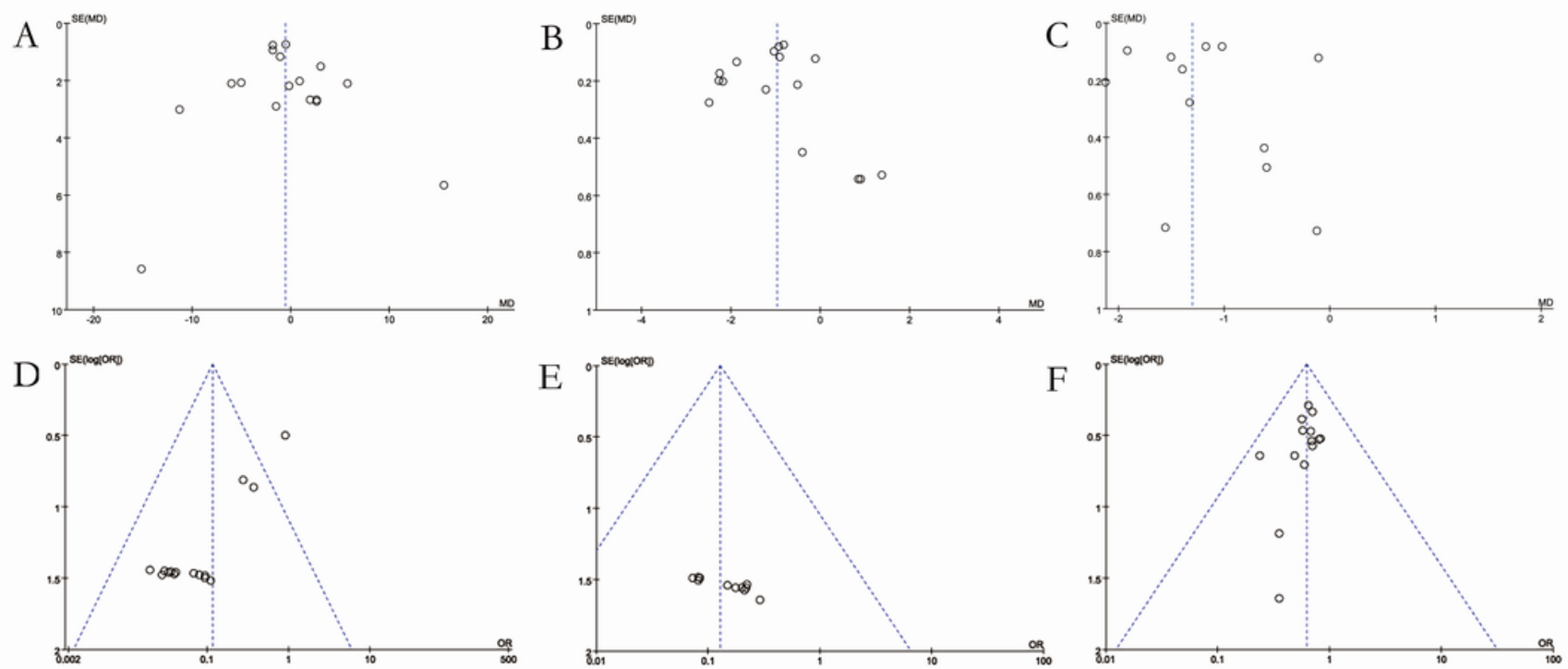
Figure 5

Funnel plot. A, operation time; B, catheterization time; C, hospitalization time; D, obturator nerve reflex; E, bladder perforation; F, 24-month recurrence rate. 